\title{
Menakar positioning dan arah branding program studi melalui pemetaan penggunaan metode riset
}

\author{
Renata Anisa ${ }^{1}$, Retasari Dewi², Hanny Hafiar ${ }^{3}$ \\ ${ }^{123}$ Universitas Padjadjaran, Bandung, Indonesia
}

\begin{abstract}
ABSTRAK
Reputasi sebuah lembaga pendidikan dapat dilihat kualitas lulusannya. Begitu juga dengan reputasi Program Studi Public Relations di Fakultas Ilmu Komunikasi, Universitas Padjadjaran. Salah satu kualitas lulusan Program Studi PR dapat ditinjau dari kemampuannya melakukan penelitian. Hal ini terkait dengan berbagai jenis riset yang mendasari setiap program kerja public relations. Oleh karena itu, diperlukan pemetaan lulusan sebagai langkah awal bagi program studi untuk melakukan aktivitas branding yang akan ditonjolkan oleh lembaga di mata publik. Tugas akhir mahasiswa (skripsi) dapat memberikan gambaran tren metode riset yang digunakan dan dikuasai calon praktisi public relations. Dengan demikian, tujuan penelitian ini adalah untuk memetakan metode riset yang digunakan pada penelitian (skripsi) mahasiswa pada periode tahun 2015-2019. Penelitian ini menggunakan metode deskriptif kuantitatif, dengan melakukan analisis terhadap 639 abstrak skripsi mahasiswa. Data diperoleh dari data sekunder untuk kemudian dianalisis sebagai bahan penarikan kesimpulan. Hasil penelitian menunjukkan bahwa sebagian besar skripsi mahasiswa menggunakan penelitian kualitatif dengan metode deskriptif, studi kasus, dan fenomenologi, sisanya mahasiswa menggunakan penelitian kuantitatif dengan metode uji hubungan, uji pengaruh, dan deskriptif. Hasil penelitian ini diharapkan dapat memberikan kontribusi bagi penguatan mata kuliah yang terdapat pada kurikulum program studi humas agar sesuai dengan kebutuhan pengguna lulusan, serta sebagai pertimbangan untuk menentukan arah branding program studi.
\end{abstract}

Kata-kata Kunci: Riset; metode penelitian; program studi; skripsi; public relations

\section{Measuring positioning and orientation of studies program's branding through research method's mapping}

\section{ABSTRACT}

The reputation of an educational institution can be seen from the quality of graduates. The public Relations studies program at the Faculty of Communications Sciences, Universitas Padjadjaran, cannot abandon this notion. One of the PR studies program's qualities of graduates can be seen from graduates' skills to do research related to the variety of research that becomes the basis of each $P R$ program. Therefore, a mapping of graduates is required as a first step by PR studies program to build a brand of its program studies to the public. The students' final task (thesis) can describe the research method trend used by practitioner public relations. Therefore, this research aims to map the research methods used in student research (thesis) in the period 2015-2019. This study used a quantitative descriptive method by analyzing 639 abstracts of a student thesis. Data is collected from secondary data, then interpreted as material for the conclusion. The results showed that most of the students' thesis used qualitative research with descriptive methods, case studies, and phenomenology. In contrast, others used quantitative analysis with the relationship test methods, influence test, and descriptive. This article results are expected to contribute to the strengthening of the subjects in the curriculum of public relations studies to fit users' needs and consideration to determine the direction of PR studies program branding.

Keywords: Research; research methods; studies program; thesis; public relations

Korespondensi: Renata Anisa.,S.Sos.,M.M. Universitas Padjadjaran. Jalan Raya Bandung-Sumedang KM.21.Email: renata@unpad.ac.id 


\section{PENDAHULUAN}

Perkembangan Ilmu Public Relations secara internasional, mengalami perkembangan yang pesat. Hal ini ditunjukkan dengan kemunculan sejumlah literasi dengan isu kontemporer di bidang public relations. Literasi yang berbentuk textbook, buku praktikal, bunga rampai, jurnal hingga artikel populer diberbagaimedia tersebut, menawarkan sejumlah pemikiran mengenai teori, konsep baru, serta metode yang khas di bidang public relations. Hal ini menunjukkan tingginya minat publik internasional di bidang public relations. Fenomena ini perlu direspons secara tepat oleh pengelola program studi public relations. Mengingat kompetisi antar lembaga pendidikan di bidang public relations sudah semakin ketat. Oleh karena itu diperlukan upaya branding yang dilakukan oleh program studi public relations untuk menonjolkan kekuatan dan kekhasan lembaga pendidikan yang dikelolanya. Seperti halnya Program Studi Hubungan Masyarakat (Public Relations), di Fakultas Ilmu Komunikasi, Universitas Padjadjaran.

Penyelenggaraan pendidikan Program Studi Hubungan Masyarakat di Fakultas Ilmu Komunikasi, Universitas Padjadjaran secara resmi dibuka pada November 2013. Program studi ini sebelumnya dikenal dengan Jurusan Hubungan Masyarakat. Program Studi
Hubungan Masyarakat merupakan bagian dari Fakultas Ilmu Komunikasi, Universitas Padjadjaran. Universitas ini merupakan salah satu perguruan tinggi di Indonesia dengan akreditasi peringkat A dari Badan Akreditasi Nasional Perguruan Tinggi (BAN-PT). Menurut halaman resmi di website Program Studi Hubungan Masyarakat (Humas, 2017) sebelumnya Fakultas Ilmu Komunikasi bernama Fakultas Jurnalistik dan Publisistik yang resmi dibuka pada tahun 1960. Pada tahun 1962 fakultas ini menjadi Fakultas Publisistik dan Jurnalistik. Namun, dengan mempertimbangkan kebutuhan lulusan yang terserap dunia kerja, maka diusulkan kembali perubahan nama fakultas, sehingga pada tahun 1963 berubah nama menjadi Fakultas Publisistik.

Fakultas ini secara resmi memiliki lima jurusan yakni Jurnalistik, Penerangan/ Propaganda, Public Relations, Graphic Arts/ Photography, dan Telekomunikasi/Komunikasi Massa. Selanjutnya, pada tahun 1983 Fakultas Publisistik diubah kembali namanya menjadi Fakultas Ilmu Komunikasi dengan empat jurusan yakni Jurusan Ilmu Jurnalistik, Jurusan Ilmu Hubungan Masyarakat, Jurusan Ilmu Penerangan, serta Jurusan Ilmu Informasi dan Perpustakaan. Saat ini Fakultas Ilmu Komunikasi memiliki sembilan program studi. Pada seleksi SBMPTN 2019 jumlah peminat program studi hubungan masyarakat cukup 
tinggi yakni mencapai 650 peminat, sementara kuota SBMPTN 2020 adalah 36 mahasiswa dan daya tampung melalui SNMPTN atau jalur undangan adalah 18 mahasiswa, Program Studi Hubungan Masyarakat memiliki tingkat ketetatan yang cukup tinggi.

Terdapat lebih dari enam ratus jumlah riset public relations dalam kurun waktu 2015 2019 yang dihasilkan oleh mahasiswa program studi hubungan masyarakat, Fikom, Unpad. Riset ini dihasilkan dalam bentuk tugas akhir atau skripsi mahasiswa. Selayaknya sebuah penelitian ilmiah, skripsi tersebut menggunakan metode penelitian. Riset tersebut dilakukan sebagai syarat menjadi sarjana di program studi hubungan masyarakat.

Riset public relations berkembang sering dengan perkembangan teknologi dan informasi. Tumbuhnya jumlah pengguna media internet di Indonesia, menjadi salah satu faktor yang mempengaruhi kajian public relations. Media adalah alat yang digunakan oleh public relations untuk menyampaikan berbagai informasi mengenai produk atau perusahaan kepada publiknya. Sehingga, perkembangan media berdampak pada saluran yang digunakan praktisi public relations.

Jika sebelumnya aktivitas publisitas yang dilakukan oleh public relations officer lebih banyak menggunakan media cetak seperti koran dan majalah serta media elektronik seperti televisi dan radio. Namun, di era teknologi digital saat ini, terdapat berbagai pilihan media yang dapat dimanfaatkan dalam melakukan kampanye, sosialisasi, dan periklanan. Saat ini, terdapat berbagai pilihan media berbasis internet untuk melakukan aktivitas komunikasi dan publikasi, yaitu dengan memanfaatkan media sosial resmi perusahaan, dengan biaya yang relatif lebih murah, jangkauan yang lebih luas, dan mampu meningkatkan engangement publik terhadap perusahaan. Tumbuhnya media baru tersebut memberikan kemudahan bagi PR officer di perusahaan untuk memperkenalkan dan menyampaikan berbagai informasi mengenai produk dan perusahaannya.

Seiring dengan kemunculan media baru, khususnya media sosial, ternyata mempengaruhi mahasiswa Program Studi Hubungan Masyarakat dalam memilih topik riset yang diangkat sebagai fokus kajian dalam skripsi, dalam kurun waktu 2015 2019. Beberapa topik riset yang diangkat adalah media facebook, instagram, twitter, dan youtube. Saat ini perusahaan maupun pemerintah memanfaatkan media sosial untuk berkomunikasi dengan publik. Perusahaan menyampaikan informasi produk, jasa, layanan, aktivitas perusahaan, special event yang diselenggarakan, hingga melakukan kampanye. Sementara, pemerintah memanfaatkan media sosial untuk mensosialisasikan peraturan 
dan kebijakan pemerintah, serta menampung aspirasi masyarakat.

Selain topik mengenai media sosial, terdapat beberapa bidang kajian public relations yang menarik perhatian mahasiswa untuk dijadikan sebagai bidang telaahan dalam penelitian tugas akhirnya. Di antaranya bidang kajian media relations, corporate social responsibility, marketing public relations, customer relations, hingga tools public relations. Bidang-bidang kajian ini diteliti oleh mahasiswa dengan menggunakan beragam metode penelitian.

Riset di bidang public relations dapat menggunakan penelitian kualitatif dan kuantitatif dengan berbagai metode. Penelitian kualitatif digunakan untuk meneliti fenomena sosial. Peneliti melakukan riset secara langsung ke lapangan dengan cara observasi, wawancara, dan grup diskusi. Sehingga pada saat melaksanakan proses penyelesaian skripsi dengan metode ini, mahasiswa diharapkan mampu mengasah kepekaan sosial dan meningkatkan softskill dalam aspek berinteraksi, negosiasi, investigasi, serta melakukan analisis dan sintesis antara das solen dan das sein.

Sementara, penelitian kuantitatif dapat digunakan untuk meneliti masalah yang dapat digali dengan instrumen berupa angket. Melalui penyebaran angket ini, mahasiswa diharapkan mampu mengembangkan karakter diri berupa ketekunan, serta kejujuran, dan meningkatkan softskill dalam aspek kemampuan membaca, mengolah dan menginterpretasi data berupa angka.

Kepekaan dan kemampuan dalam melakukan riset merupakan modal awal bagi sarjana di bidang Ilmu Public Relations, sebab tahapan pertama dalam penyusunan program public relations adalah riset dan analisis situasi. Pada tahap ini, seorang praktisi PR diharapkan mampu melakukan analisis yang mendasar seperti memetakan kekuatan, kelemahan, peluang, dan hambatan yang akan dihadapi perusahaan. Tahap berikutnya adalah perencanaan, pelaksanaan, dan diakhiri dengan evaluasi.

Kemampuan meneliti dari seorang sarjana public relations akan sangat dibutuhkan saat berada pada tahap fact finding, karena ia akan dituntut untuk mampu melakukan aktivitas pra riset sebelum program ditetapkan Tahapan ini dilakukan misalnya: untuk mengetahui sesuatu yang sedang terjadi dalam organisasi, pendapat atau sikap masyarakat terhadap organisasi, faktor pendukung dan penghambat aktivitas organisasi, dan lain-lain.

Begitu juga saat tahapan melakukan perencanaan, sarjana public relations diharapkan mampu melakukan perancangan strategi dan taktik yang dapat membantu menyelesaikan masalah yang dihadapi organisasi. Sedangkan pada tahap pelaksanaan yang merupakan 
implementasi dari perencanaan program, seorang sarjana public relations diharapkan mampu membangun aktivitas komunikasi secara efisien melalui berbagai bentuk dan media komunikasi yang sesuai dengan target sasaran.

Adapun pada tahap evaluasi, seorang sarjana public relations diharapkan mampu melakukan penilaian atau evaluasi terhadap program yang telah direncanakan dan dilakukan. Hal ini akan berkaitan dengan pengukuran tingkat keberhasilan dalam mencapai tujuan, menghitung dampak program terhadap target sasaran, serta melakukan prediksi berdasarkan pengalaman. Hasil evaluasi dapat digunakan untuk pengambilan kebijakan dan perencanaan program yang dilakukan oleh organisasi. Oleh sebab itu PR officer memiliki peran yang signifikan dalam menginisiasi dan mengawal aktivitas organisasi yang berkaitan dengan berbagai jenis publik, secara efektif dan efisien.

Kemampuan untuk melakukan berbagai jenis aktivitas mulai dari proses fact finding hingga evaluasi dapat dikembangkan melalui aktivitas meneliti dalam rangka penyelesaian tugas akhir berupa skripsi. Oleh karena itu, sebagai persiapan sebelum terjun di dunia kerja, sudah seharusnya lulusan Program Studi Public Relations mampu melakukan riset dengan berbagai metode. Hal ini dimaksudkan agar perusahaan atau organisasi dapat langsung merasakan manfaat dari sarjana public relations yang dipekerjakannya, tanpa harus melalui proses adaptasi yang lama. Pada prinsipnya, sebuah perusahaan akan berharap bahwa sarjana public relations yang dipekerjakannya akan dapat membantu organisasi untuk melakukan aktivitas organisasi. Keberadaan seorang pekerja yang siap dan mampu bekerja tentu akan menghasilkan kepuasan perusahaan atas hasil kerja yang ditunjukkannya. Kepuasan perusahaan atas hasil kerja sarjana public relations ini lah yang diharapkan mampu meningkatkan reputasi program studi public relations.

Melakukan penelitian, tak hanya sekedar meningkatkan keterampilan dalam aspek analisis dan sintesis, namun juga mengasah kemampuan berkomunikasi secara lisan maupun tulisan yang bersifat argumentatif dan ilmiah dalam melakukan proses pencarian dan pemaparan data. Kemampuan ini diharapkan akan membekali sarjana public relations saat melakukan komunikasi publik. Sebab, public relations officer dapat berfungsi pula sebagai juru bicara perusahaan, yang berperan untuk menjawab dan menjelaskan berbagai pertanyaan dari masyarakat, media, komunitas, dan pemerintah mengenai produk atau perusahaan.

Penelitian public relations di Amerika banyak dilakukan oleh akademisi, tujuannya untuk membangun teori, memberikan gambaran, 
menjelaskan dan memprediksi proses dan efek public relations dalam masyarakat (Ardianto, 2011). Namun, perlu digaris bawahi, bahwa aktivitas meneliti bukan merupakan ranah dominasi akademisi saja. Seorang praktisi public relations pun dituntut untuk mampu melakukan penelitian baik secara formal dan non formal, dalam bentuk mini riset atau jenis riset yang kompleks sekalipun.

Praktisi humas dewasa ini, diharapkan mampu membuat pemetaan dan juga mencari tahu persoalan-persoalan yang dihadapi organisasi atau perusahaan, termasuk saat menghadapi stakeholders dengan berbagai karakter. Pemahaman mengenai persoalan yang berkaitan dengan stakeholders hanya bisa dijangkau melalui kemampuan dan kepiawaian untuk menembus esensi masalah yang antara lain dapat dieksplorasi melalui kegiatankegiatan riset. Karena itu, sangat penting bagi seorang praktisi humas untuk selalu terbiasa mendapatkan atau menyentuh jantung persoalan melalui aktivitas riset (Gani, 2013). Menurut hasil riset yang dilakukan oleh Foundation of International Associatiton of Business Communicators (IABC) menunjukkan bahwa menggunakan penelitian (bukan intuisi, tebakan, firasat, asumsi pribadi) dapat memberikan perspektif yang lebih luas dan menjadi alasan kinerja public relations kala itu diapresiasi (Grunig, 2018).
Kurikulum program studi hubungan masyarakat disusun dan dirancang untuk mencapai profil lulusan yakni corporate communication, konsultan public relations, publicist dan event organizer. Hal ini sejalan dengan visi Program Studi Hubungan Masyarakat, Fikom, Unpad, yakni menjadi program studi yang memiliki komitmen untuk mengembangkan ilmu hubungan masyarakat dan menjadi pusat studi hubungan masyarakat yang diakui di tingkat lokal, nasional, maupun internasional serta mampu beradaptasi terhadap perubahan di tingkat lokal, nasional, dan internasional di tahun 2026 (Humas, 2017). Oleh karena itu, beberapa mata kuliah di dalam kurikulum yang telah disesuaikan dengan profil lulusan. Adapun mata kuliah yang terkait langsung dengan teknik penelitian, diantaranya: metode penelitian humas kualitatif, metode penelitian humas kuantitatif, riset media, audit humas, dan statistika sosial.

Selanjutnya, Program studi hubungan masyarakat juga telah menyusun capaian pembelajaran yakni aspek sikap di antaranya mengkolaborasikan semangat multidisiplin dan berinteraksi dengan masyarakat, bekerjasama dan memiliki kepekaan sosial serta kepedulian terhadap masyarakat dan lingkungan serta berkontribusi dalam peningkatan mutu kehidupan bermasyarakat, berbangsa, bernegara, dan kemajuan peradaban 
berdasarkan Pancasila. Guna pencapaian tujuan pembelajaran tersebut, maka mahasiswa diharapkan memiliki pengetahuan secara konsep dan teoritis, serta keterampilan dalam melakukan praktik-praktik public relations.

Pengetahuan konsep dan teori tentang kehumasan akan membekali mahasiswa tentang posisi, fungsi, dan praktik humas dalam berbagai setting organisasi, baik pemerintah, swasta, atau lembaga swadaya masyarakat. Untuk memperdalam penguasaan materi, maka mahasiswa diharapkan juga dapat menguasai kaidah, prinsip, dan teknik komunikasi lintas fungsi, level organisasi dan budaya. Penguasaan materi-materi tersebut diharapkan akan mendukung upaya terwujudnya capaian pembelajaran.

Capaian pembelajaran dapat diklasifikasikan ke dalam bentuk keterampilan umum dan keterampilan khusus. Keterampilan umum, mengacu pada sasaran membekali lulusan agar mampu menunjukkan kinerja mandiri, bermutu, terukur, mampu menerapkan pemikiran logis, kritis, sistematis, dan inovatif dalam pengembangan atau implementasi ilmu pengetahuan dan teknologi yang memperhatikan dan menerapkan nilai humaniora yang sesuai dengan bidang keahliannya (Humas, 2017).

Sedangkan untuk capaian pembelajaran pada aspek keterampilan khusus diantaranya mahasiswa diharapkan mampu mendesain, melaksanakan, dan mengevaluasi program, mengelola media, menulis siaran pers serta mampu mengidentifikasi, menganalisis isu-isu terkini yang strategis, guna menyusun alternatif solusi di bidang kehumasan. Pada tahapan ini, dibutuhkan pengetahuan dan keterampilan untuk melakukan riset dengan berbagai metode.

Oleh karena itu, perlu dilakukan kajian mengenai trend penggunaan metode riset dalam karya ilmiah lulusan program studi public relations, untuk selanjutnya dapat dipetakan trend isu, dan jenis metode dalam tugas akhir mahasiswa sebagai langkah awal evaluasi diri, guna mengembangkan kurikulum dan menajamkan materi dalam tiap mata kuliah.

Terdapat beberapa riset terdahulu yang menggunakan skripsi sebagai data utama dalam melakukan penelitian, di antaranya analisis tugas akhir mahasiswa (Indarto, 2012), riset literatur yang melakukan analisis sitiran terhadap skripsi (Isbandini, 2016), analisis tentang tren perkembangan penelitian mahasiswa (Yanto \& Erwina, 2017), serta analisis terhadap hasil-hasil tugas akhir mahasiswa (Pujianto \& Suyoso, 2011). Beberapa temuan dari hasil riset tersebut antara lain dapat menjadi bahan pemikiran mengenai pengembangan isu-isu penelitian, kualitas tugas akhir, baik secara teknis maupun substantif.

Selanjutnya, riset ini juga dilakukan peneliti dengan maksud menegaskan branding 
Program Studi Hubungan Masyarakat, Fikom, Unpad, di antara sekian banyak Program Studi Hubungan Masyarakat di berbagai perguruan tinggi di Indonesia. Reputasi yang dimiliki lembaga pendidikan akan merujuk pada kualitas pendidikan sekaligus menjadi indikator keberhasilan (Kurnia, Santoso, \& Rahmanto, 2013). Oleh sebab itu, sudah sepatutnya lembaga pendidikan mengupayakan pembentukan positioning dan melakukan branding lembaga (Prastantri, Novianti, \& Romli, 2017), guna menghasilkan reputasi. Reputasi dapat dibentuk melalui penetapan posisi lembaga pada aspek diferensiasi di bandingkan lembaga sejenis, serta upaya branding, untuk melekatkan citra lembaga di mata publiknya. Oleh karena itu, insan cendekia yang berada di dalam lembaga pendidikan yang berkonsentrasi untuk menghasilkan sarjana public relations, sudah semestinya mendalami manajemen isu (Prayudi, 2013), seputar reputasi lembaga, baik ditinjau dari sudut posisi sebagai akademisi maupun praktisi.

Terdapat beberapa riset mengenai Peran humas dalam meningkatkan citra Universitas (Rini, Rusmiwari, \& Widodo, 2017), dan juga Peran Public Relations Di Perguruan Tinggi Negeri di Era Badan Hukum Pendidikan Tinggi (Farouk, 2010). Keduanya menekankan adanya aktivitas public relations yang berperan penting dalam pembentukkan citra lembaga perguruan tinggi. Citra dan reputasi Program Studi Hubungan Masyarakat, Fikom, Unpad, tidak akan terbentuk begitu saja tanpa upaya branding guna menghasilkan opini publik yang positif terhadap lembaga. Sebab, respon terhadap pencitraan lembaga pendidikan tergantung pada persepsi, realitas dan opini publik yang terbentuk seiring berjalannya waktu dalam membangun reputasi sekolah (Kurnia et al., 2013)

Oleh karena itu, tujuan dari penelitian ini dapat dirumuskan sebagai kajian untuk memetakan kecenderungan penggunaan metode dalam riset public relations, dengan menggunakan data berupa hasil penelitian atau karya ilmiah (skripsi) mahasiswa di Program Studi Hubungan Masyarakat, Fikom Unpad, pada periode tahun 2015-2019.

\section{METODE PENELITIAN}

Metode yang digunakan dalam penelitian ini adalah deskriptif kuantitatif. Metode ini dipakai untuk memberikan gambaran mengenai preferensi penggunaan metode riset yang digunakan dalam penelitian mahasiswa Program Studi Hubungan Masyarakat, Fikom, Unpad. Pada prinsipnya, metodologi adalah suatu pendekatan umum untuk mengkaji suatu topik penelitian (Mulyana \& Solatun, 2007). Metode penelitian merupakan cara ilmiah 
untuk memperoleh data dengan tujuan tertentu (Sugiyono, 2014). Oleh karena itu, dalam penelitian ini, peneliti melakukan analisis ilmiah atas data yang diperoleh guna memberikan gambaran tentang kecenderungan penggunaan metode riset pada karya ilmiah mahasiswa.

Adapun teknik pengumpulan data dilakukan melalui pencarian dan penemuan bukti-bukti yang disebut sebagai kajian dokumen. Dokumen yang dianalisis berupa dokumen yang berupa data sekunder. Data sekunder diperoleh dari data repositori skripsi mahasiswa Program Studi Hubungan Masyarakat Fakultas Ilmu Komunikasi, yang tersimpan dalam rekapitulasi administrasi Program Studi Hubungan Masyarakat. Dari skripsi-skripsi tersebut kemudian dilakukan analisis subjek, dengan memetakan keyword pada bagian abstrak.

Populasi dalam penelitian ini adalah seluruh skripsi mahasiswa Program Studi Hubungan Masyarakat, Fakultas Ilmu Komunikasi, dari tahun 2015 sampai dengan 2019 yang berjumlah 639 judul skripsi. Sedangkan untuk analisis data dilakukan penghitungan frekuensi dengan menggunakan rumus persentase:

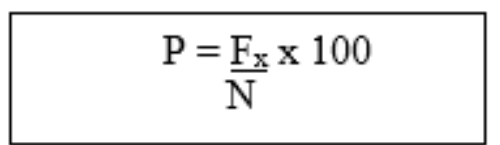

Keterangan:
$\mathrm{P}=$ Jumlah Persentase

$\mathrm{F}_{\mathrm{x}}=$ Frekuensi individu

$\mathrm{N}=$ Jumlah Kejadian

Sumber: (Bungin, 2005).

Prosedur pengolahan data penelitian ini antara lain a) pemeriksaan data; b) klasifikasi data; c) tabulasi data berdasarkan klasifikasi yang dibuat periset; d) menghitung frekuensi data; e) perhitungan lebih lanjut sesuai teknik statistika yangn dipilih yakni prosentasi; f) memvisualisasikan data; g) menafsirkan data sesuai pertanyaan penelitian (Sudjana \& Ibrahim, 2007).

Untuk memperoleh data yang tepat, peneliti melakukan uji ketepatan data dengan menyusun kisi-kisiinstrumen yangdigunakanselamaproses pengumpulan sumber data, proses penghitungan frekuensi data, proses perhitungan statistik dan proses visualisasi data (Na'imah, 2013). Data skripsi program studi hubungan masyarakat pada tahun 2015 - 2019 dikumpulkan, untuk kemudian diklasifikasikan berdasarkan jenis penelitian yang digunakan yakni kualitatif dan kuantitatif. Data penelitian kuantitatif tersebut kemudian diklasifikasikan kembali berdasarkan metode yang digunakan yakni deskriptif, uji hubungan, serta uji pengaruh. Sedangkan untuk penelitian kualitatif, diklasifikasikan menjadi metode deskriptif, studi kasus, fenomenologi, etnografi serta analisis teks (semiotik, wacana, isi). Data tersebut divalidasi untuk kemudian 
dilakukan verifikasi. Selanjutnya, dilakukan perhitungan statistik yakni persentase, untuk kemudian digambarkan dalam bentuk tabel, dan grafik visual. Data tersebut dianalisis serta diinterpretasikan dan terakhir ditarik kesimpulan berdasarkan pertanyaan penelitian.

\section{HASIL DAN PEMBAHASAN}

Dari sampel yang di dokumentasikan peneliti, terdapat 639 judul skripsi pada periode tahun 2015 - 2019 di program studi hubungan masyarakat. Peneliti melakukan koding terhadap judul, penelitian, tahun lulus, jenis penelitian, dan metode penelitian. Data jumlah skripsi berdasarkan tahun penelitian yang berhasil diidentifikasi disajikan dalam tabel 1 .

Pada tahun 2015 terdapat 123 judul skripsi di Program Studi Hubungan Masyarakat artinya program studi ini meluluskan 123 mahasiswa pada tahun tersebut. Tahun 2017 dan 2018 terdapat 190 dan 200 judul skripsi. Pada

Tabel 1 Koding Jumlah Sampel

\begin{tabular}{lll}
\hline Tahun & Jumlah skripsi & Persentase \\
\hline 2015 & 123 & $19.2 \%$ \\
2016 & 190 & $29.7 \%$ \\
2017 & 200 & $31.3 \%$ \\
2018 & 81 & $12.7 \%$ \\
2019 & 45 & $7.0 \%$ \\
Total & 639 & $100 \%$ \\
\hline
\end{tabular}

Sumber : Rekapitulasi administrasi di Program studi Hubungan Masyarakat Fikom Unpad, 2020 tahun 2014 terjadi perubahan status dimana sebelumnya jurusan hubungan masyarakat yang berada di bawah Program Studi Ilmu Komunikasi, menjadi Program Studi Hubungan Masyarakat. Perubahan ini berdampak pada daya tampung mahasiswa program studi sesuai dengan kebijakan Badan Akreditasi Perguruan Tinggi Negeri (BAN-PT) dan universitas. Sehingga pada tahun 2018 hingga 2019 Program Studi Hubungan Masyarakat mengalami penurunan jumlah mahasiswa hingga lebih dari $50 \%$ dan berdampak pada penurunan jumlah penelitian (riset). Perubahan jumlah mahasiswa Program Studi Hubungan Masyarakat disajikan dalam tabel 2 .

Pada tabel 2 ditampilkan jumlah mahasiswa Program Studi Hubungan Masyarakat berjumlah di atas 100 mahasiswa, atau ratarata 156 mahasiswa sejak 2010 hingga 2013. Berjumlah 54 mahasiswa di tahun 2014 dan pada tahun pertama perubahan status menjadi

Tabel 2 Jumlah mahasiswa Program Studi Hubungan Masyarakat

\begin{tabular}{cc}
\hline Tahun & Jumlah \\
\hline 2010 & 146 \\
2011 & 204 \\
2012 & 103 \\
2013 & 173 \\
2014 & 54 \\
2015 & 56 \\
2016 & 112 \\
\hline
\end{tabular}

Sumber : Data administrasi, 2019 
program studi, terdapat 56 mahasiswa di tahun 2015. Jumlah mahasiswa kembali meningkat di tahun 2016 sebanyak 112 mahasiswa. Perubahan jumlah mahasiswa, tentu saja berdampak pada jumlah lulusan program studi empat tahun kemudian atau tahun 2018. Di tahun 2018 terdapat 81 judul skripsi dan tahun 2019 terdapat 45 judul skripsi.

Pemetaan riset mahasiswa Program Studi Hubungan Masyarakat dibagi kedalam beberapa jenis penelitian, pada riset ini peneliti akan membahas mengenai metode penelitian yang digunakan mahasiswa. Sebanyak 639 skripsi yang dikategorikan dalam dua kategori yakni kuantitatif dan kualitatif.

Berdasarkan pada gambar 1, jumlah penelitian pada periode tahun 2015-2019 dengan menggunakan jenis penelitian kualitatif

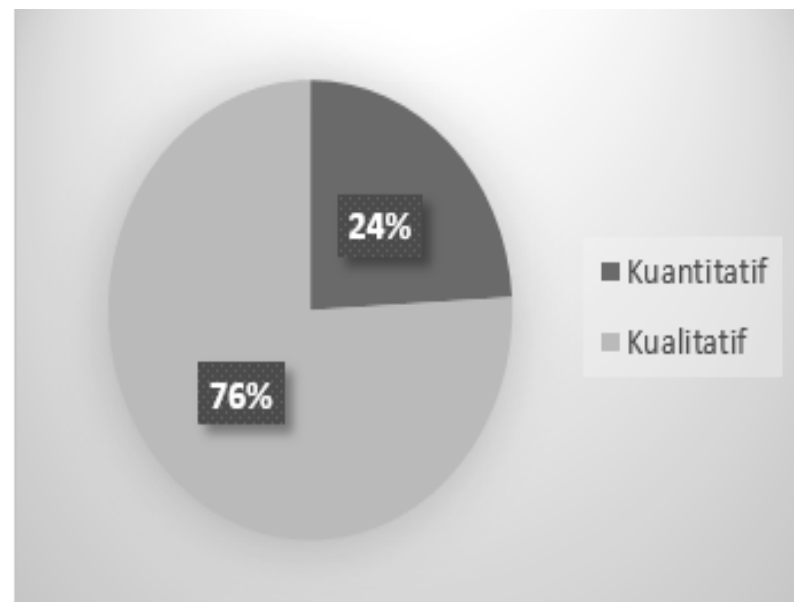

Sumber : Data penelitian, 2020

Gambar 1 Diagram perbandingan jenis penelitian yang digunakan dalam skripsi lulusan Program Studi Hubungan Masyarakat 2015-2019 lebih banyak dibandingkan dengan kuantitatif. Perbedaannya sangat signifikan hingga mencapai 300\%. Hal ini menunjukkan penelitian kualitatif lebih diminati untuk dilakukan oleh mahasiswa dibandingkan penelitian kuantitatif. Berdasarkan kepentingan sebuah penelitian, perlu dipertimbangkan mengenai karakterisik dan jenis data yang dibutuhkan. Jenis data dibagi menjadi dua yakni kualitatif dan kuantitatif. Kualitatif, menghasilkan data-data dalam bentuk teks atau narasi yang berasal dari studi kepustakaan, wawancara, dan observasi. Sementara, kuantitatif menghasilkan data-data dalam bentuk angka yang berasal dari angket atau kuesioner, yang dilanjutkan dengan pengolahan statistik.

Pada riset-riset public relations, kualitatif banyak digunakan oleh mahasiswa, penelitian kualitatif dianggap mampu menggambarkan dan menjelaskan lebih mendalam suatu fenomena sosial yang mungkin sulit diukur dan digambarkan melalui penelitian kuantitatif. Penelitian kualitatif dapat menghasilkan penemuan fenomena baru berdasarkan penggalian data yang mendalam.

Penelitian kualitatif juga dikatakan lebih dinamis, dapat berkembang sesuai dengan kebutuhan penelitian, sehingga penelitian kualitatif lebih menekankan pada seberapa dalam peneliti dapat menggali informasi dari narasumber dibandingkan dengan jumlah 
narasumber yang berhasil di wawancara. Hasil dari penelitian kualitatif dapat berupa deskripsi dari interpretasi peneliti dan terbatas pada situasi tertentu sehingga tidak dapat digeneralisasikan. Sementara, penelitian kuantitatif biasanya digunakan untuk meneliti sejumlah populasi dan sampel penelitian. Penelitian kuantitatif lebih terencana dan statis dengan subjek penelitian yang biasa disebut responden dengan menggunakan instrumen angket atau kuesioner, data tersebut diolah secara statistik dengan indikator tertentu sesuai dengan variabel atau dimensi pada kerangka penelitian. Kualitas penelitian kuantitatif dapat dilihat dari jumlah responden yang terlibat. Serta faktor reliabilitas dan validitas kuesioner. Pada penelitian kuantitatif, fenomena sosial yang diteliti dapat digeneralisasikan, hal ini berbeda dengan penelitian kualitatif yang bergantung pada situasi yang diteliti.

Data temuan mengenai jenis penelitian yang digunakan dalam riset public relations tersebut, diklasifikasikan berdasarkan tahun riset, jumlah jenis penelitian yang digunakan dalam skripsi, serta prosentasenya, seperti tergambar dalam tabel 3 dan tabel 5.

Tabel 3 menunjukkan data riset menggunakan penelitian kuantitatif yang dibagi berdasarkan tahunnya. Jika dirata-ratakan maka tiap tahunnya penelitian menggunakan penelitian kuantitatif dalam lima tahun terakhir sebanyak 30 judul skripsi, dan persentasenya tidak mencapai $10 \%$ dari total jumlah skripsi. Penelitian kuantitatif terlihat paling banyak di tahun 2016 sebanyak 55 judul skripsi atau 8.6\% dari total judul skripsi. Jumlah paling sedikit di tahun 2019 sebanyak 5 judul skripsi atau $0.8 \%$ dari total judul skripsi. Skripsi mahasiswa dengan menggunakan penelitian kuantitatif dalam rentang tahun 2015-2019 dibagi kedalam tiga metode yaitu uji hubungan, uji pengaruh dan deskriptif.

Tabel 3 Persentase penelitian menggunakan metodologi kuantitatif dan kualitatif

\begin{tabular}{ccccc}
\hline Tahun & $\begin{array}{c}\text { Kuantitatif } \\
\text { Jumlah skripsi }\end{array}$ & Persentase & $\begin{array}{c}\text { Kualitatif } \\
\text { Jumlah skripsi }\end{array}$ & Persentase \\
\hline 2015 & 35 & $5.5 \%$ & 88 & $13.8 \%$ \\
2016 & 55 & $8.6 \%$ & 135 & $21.1 \%$ \\
2017 & 43 & $6.7 \%$ & 157 & $24.6 \%$ \\
2018 & 16 & $2.5 \%$ & 65 & $10.2 \%$ \\
2019 & 5 & $0.8 \%$ & 40 & $6.3 \%$ \\
Jumlah & 154 & $24.1 \%$ & 485 & $75.9 \%$ \\
\hline
\end{tabular}




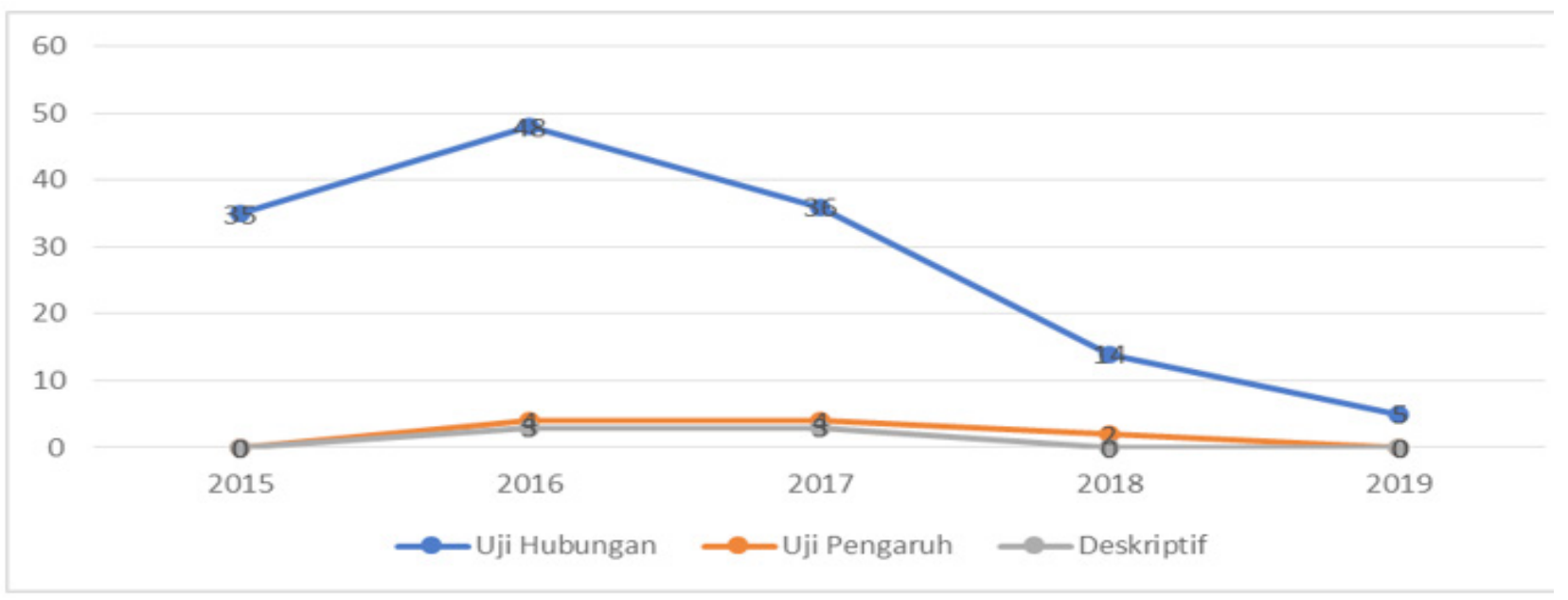

Sumber : Hasil olah data peneliti, 2020

Gambar 2 Trend penggunaan metode dalam penelitian kuantitatif pada skripsi

Data pada gambar 2 menunjukkan metode uji hubungan menempati metode penelitian yang paling banyak digunakan dalam skripsi dari tahun ketahun yaitu sebanyak 138 judul. Jika di persentasekan maka penelitian menggunakan metode uji hubungan mencapai $89.6 \%$ dari total penelitian kuantitatif, dan $21.6 \%$ dari total data skripsi. Metode uji hubungan digunakan untuk mengetahui adanya hubungan antara satu variabel dengan variabel lainnya, serta mengetahui tingkat hubungan atau tinggi rendahnya hubungan antara variabel tersebut.

Untuk penelitian yang menggunakan metode uji pengaruh dan deskriptif, hasilnya tidak terpaut jauh. Metode uji pengaruh dalam lima tahun terakhir digunakan sebanyak 10 judul atau $6.5 \%$ dari total penelitian kuantitatif dan $1.6 \%$ dari total penelitian. Uji pengaruh digunakan untuk mengetahui apakah terdapat pengaruh antara satu variabel dengan variabel lainnya serta mengetahui tingkat pengaruh atau kuat lemahnya pengaruh antar variabel tersebut. Sedangkan metode deskriptif kuantitatif selama lima tahun terakhir hanya digunakan 6 judul skripsi sebagai metode penelitian atau 3.9\% dari total penelitian kuantitatif dan $0.9 \%$ dari keseluruhan judul skripsi. Metode ini digunakan untuk mendeskripsikan atau menjelaskan peristiwa tertentu dalam bentuk angka. Hasil penelitian diperolah dari perhitungan statistik berdasarkan variabel penelitian yang kemudian dideskripsikan oleh peneliti.

Data dalam Tabel 4 menunjukkan data jumlah skripsi menggunakan penelitian kualitatif dibagi berdasarkan tahunnya. Jika dirata-ratakan, maka tiap tahunnya penelitian kualitatif dalam lima tahun terakhir sebanyak 97 judul skripsi, dan persentasenya diatas 
Tabel 4 Tabulasi jenis penelitian dan metode penelitian yang digunakan dalam skripsi

\begin{tabular}{|c|c|c|c|c|c|}
\hline Jenis penelitian & Metode & 2015-2019 & $\begin{array}{l}\text { Prosentase dari } \\
\text { jenis penelitian }\end{array}$ & $\begin{array}{l}\text { Prosentase } \\
\text { keseluruhan skripsi }\end{array}$ & dari \\
\hline \multirow[t]{4}{*}{ Kuantitatif } & Uji Hubungan & 138 & $89.6 \%$ & $21.6 \%$ & \\
\hline & Uji Pengaruh & 10 & $6.5 \%$ & $1.6 \%$ & \\
\hline & Deskriptif & 6 & $3.9 \%$ & $0.9 \%$ & \\
\hline & Total & 154 & $100 \%$ & $24.1 \%$ & \\
\hline \multirow[t]{6}{*}{ Kualitatif } & Deskriptif & 338 & $69.7 \%$ & $52.9 \%$ & \\
\hline & Studi kasus & 73 & $15.1 \%$ & $11.4 \%$ & \\
\hline & Analisis teks & 9 & $5,49 \%$ & $4,1 \%$ & \\
\hline & Etnografi & 1 & $0.2 \%$ & $0.2 \%$ & \\
\hline & Fenomenologi & 47 & $9.7 \%$ & $7.4 \%$ & \\
\hline & Total & 485 & $100 \%$ & $75,9 \%$ & \\
\hline
\end{tabular}

Sumber : Hasil olah data peneliti, 2020

$10 \%$ dari total jumlah skripsi kecuali tahun 2019. Penelitian kualitatif paling digunakan di tahun 2017 sebanyak 157 judul skripsi atau $24.6 \%$ dari total judul yakni 639 judul. Jumlah paling sedikit ada di tahun 2019 sebanyak 40 judul skripsi atau $6.3 \%$ dari total judul, namun jumlah ini sesungguhnya adalah $88 \%$ dari total judul skripsi pada tahun tersebut. Penelitian mahasiswa dengan menggunakan penelitian kualitatif dalam rentang tahun 2015-2019 dibagi kedalam 5 metode yaitu deskriptif, studi kasus, analisis teks, etnografi, dan fenomenologi.

Berdasarkan gambar 3, jika diurutkan dari jumlah penelitian kualitatif, metode yang paling banyak digunakan adalah deskriptif. Dilanjutkan dengan metode studi kasus, fenomenologi, analisis teks dan terakhir yang paling sedikit digunakan adalah metode etnografi.

Jika diuraikan jumlah judul skripsi yang menggunakan metode deskriptif sebanyak 338 judul, atau $69.7 \%$ dari jumlah total penelitian kualitatifdan52.9\% daritotalkeseluruhanskripsi. Metode ini digunakan untuk menggambarkan atau menjelaskan keadaan tertentu berdasarkan fakta yang ditemukan oleh peneliti baik melalui observasi, wawancara, maupun diskusi dengan narasumber. Riset dengan metode studi kasus, mencapai 73 judul atau $15.1 \%$ dari jumlah total penelitian kualitatif dan $11.4 \%$ dari total keseluruhan skripsi. Metode studi kasus digunakan untuk memperoleh informasi secara mendalam mengenai suatu peristiwa tertentu. Metode fenomenologi menempati urutan ketiga terbanyak digunakan dengan jumlah skripsi mencapai 47 judul atau 9.7\% dari jumlah total penelitian kualitatif dan $7.4 \%$ dari total keseluruhan skripsi. Metode fenomenologi digunakan untuk memahami esensi dari suatu 


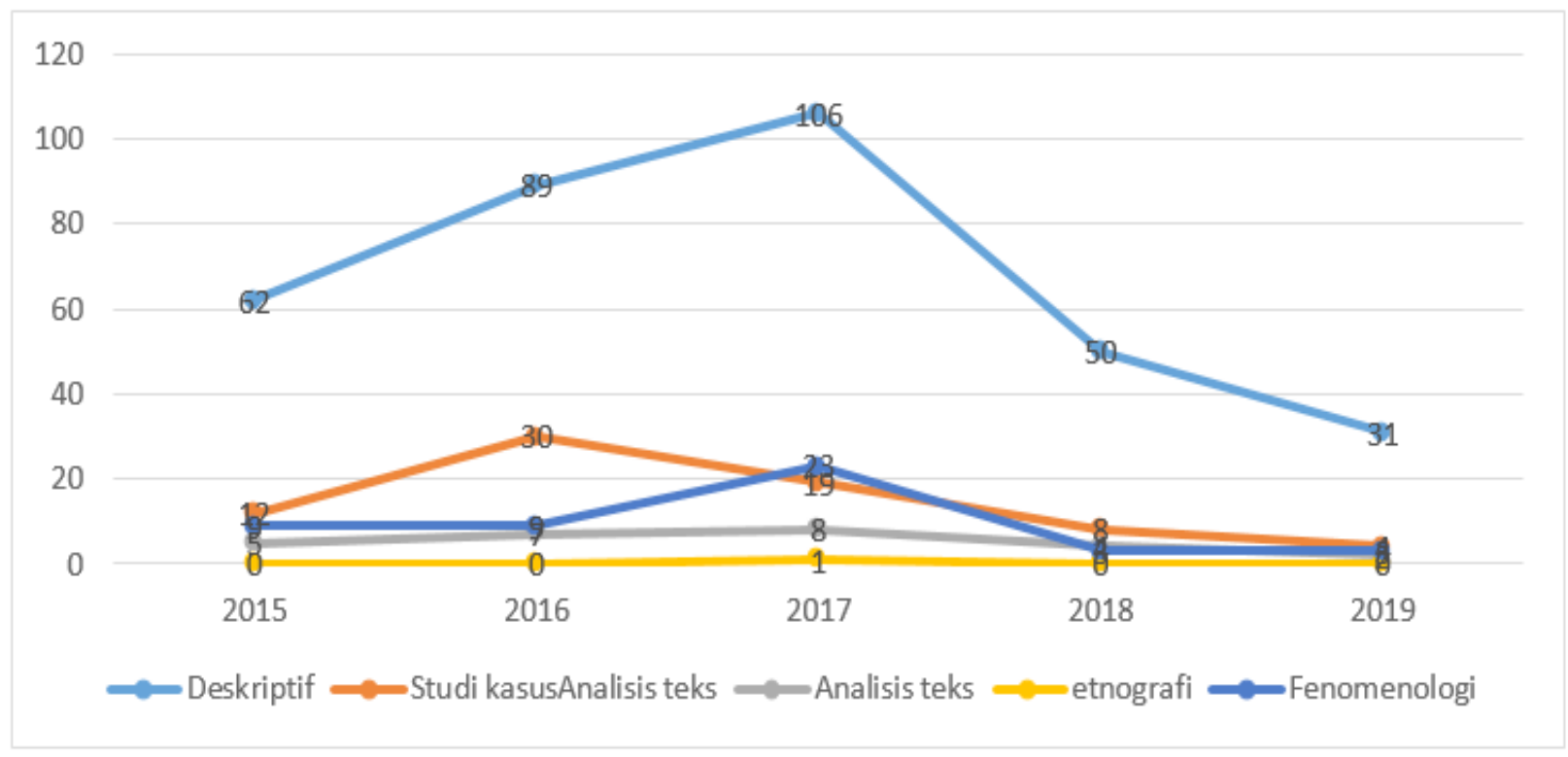

Sumber : Hasil olah data peneliti, 2020

Gambar 3 Trend penggunaan metode dalam penelitian kualitatif pada skripsi

fenomena tertentu yang dialami oleh individu maupun kelompok. Peneliti mengumpulkan pengalaman dari berbagai individu untuk ditemukan kesamaan maknanya.

Metode analisis teks dan etnografi adalah metode yang jarang digunakan dalam penelitian di Program Studi Hubungan Masyarakat. Metode analisis teks digunakan untuk mengkaji dan memahami suatu teks yang terdapat pada buku, puisi, koran, maupun majalah. Teks tersebut merupakan pesan-pesan yang disampaikan melalui berbagai media. Selama lima tahun metode analisis teks pernah digunakan di 26 judul skripsi dan metode etnografi hanya pernah digunakan satu kali di tahun 2017.

Perbedaan yang signifikan antara jumlah riset dengan menggunakan penelitian kualitatif dan kuantitatif mengundang pertanyaan lebih lanjut, mengenai gambaran arah penelitian bidang public relations secara umum atau gambaran kurikulum yang ada di program studi. Pilihan dalam metode penelitian di tiap kategori pun jumlahnya tidak merata. Misalnya kategori penelitian kuantitatif, terdapat 138 judul yang menggunakan metode uji hubungan, sedangkan metode lain yakni uji pengaruh dan deskriptif hanya 10 judul dan 6 judul. Demikian pula penelitian yang menggunakan kualitatif, jumlah metode deskriptif mencapai 338 judul skripsi, sedangkan sisanya tidak lebih dari 80 judul skripsi.

Sebagai syarat untuk lulus dan memperoleh gelar sarjana ilmu komunikasi bidang 
hubungan masyarakat, skripsi atau penelitian adalah tugas akhir yang harus diselesaikan oleh mahasiswa. Setelah menyelesaikan penelitiannya dan dinyatakan lulus, mahasiswa dianggap telah menguasai salah satu capaian pembelajaran yakni penelitian. Namun, perbedaan yang signifikan antara jumlah penelitian menggunakan kuantitatif dan kualitatif, mengarahkan peneliti untuk meneliti lebih jauh untuk memetakan penggunaan metode penelitian dan kecenderungan arah penelitian mahasiswa program studi hubungan masyarakat.

Sebuah riset dapat menjadi alat untuk menguji sebuah ide. Program public relations dihasilkan dari ide-ide yang dikembangkan oleh para praktisi, sama seperti hipotesis penelitian yang dihasilkan oleh para akademisi. Setiap metode riset memiliki alat ukur yang berbeda-beda untuk menguji sebuah hipotesis atau menjelaskan sebuah fenomena, akan tetapi semua menjadi tidak bernilai jika tidak didahului dengan konsep yang matang. Jadi, kemampuan utuk merumuskan langkah-langkah berfikir secara logis, sistematis tentang konsep, definisi, ukuran dan hubungan menjadi penting (Grunig, 2018), untuk dikuasai oleh praktisi kehumasan.

Dalam sebuah studi yang mengambil sampel 110 departemen public relations dari berbagai bidang di Uni Emirates Arab (UEA) kebanyakan mereka memilih penelitian kuantitatif dibandingkan kualitatif. Penelitian kuantitatif karena dianggap lebih mudah, lebih cepat, lebih jelas dan lebih akurat dalam merangkum berbagai informasi dalam sekali survei (Neaimi et al., 2016). Berbeda dengan studi di Uni Emirates Arab (UEA) dalam pemetaan metodologi di program studi hubungan masyarakat, penelitian kuantitatif adalah metode yang lebih jarang digunakan dalam skripsi. Penelitian kuantitatif hanya 24\% dari total sampel penelitian selama lima tahun atau sejumlah 154 judul. Metode yang paling banyak digunakan oleh peneliti setiap tahunnya adalah metode uji hubungan kemudian dilanjutkan oleh pengaruh dan deskriptif. Sebagian besar peneliti menggunakan metode uji hubungan yakni untuk mengetahui adanya hubungan antara satu variabel dengan variabel lainnya.

Dengan data tersebut, periset mampu melakukan tabulasi silang data dengan variable pendapat dan sikap. Dengan mengetahui publik yang spesifik, periset dapat merancang pesan di masa datang dengan saluran dan bahasa yang sesuai dengan target sasaran. Melalui langkah membuat segmentasi publik, periset atau public relations mengetahui tentang peta publik yang mendukung organisasi, menentang organisasi, dan komunikasi, pesan dan nilai yang beresonansi dengan setiap segmen dalam publik sasaran. Setelah berhasil mengidentifikasikan 
kelompok-kelompok ini, periset atau public relations officer dapat membangun hubungan dengan kelompok segmen tertentu untuk melakukan penelitian informasi, agar dapat lebih memahami posisi publik dan membantu untuk mewakili nilai-nilai dan keinginan publik tersebut dalam pengambilan keputusan organisasi dan pembentuk kebijakan.

Penelitian dilakukan untuk mengidentifikasi kebutuhan dan permasalahan publik agar perusahaan dapat menentukan program sesuai dengan kebutuhan permasalah publik, namun karakteristik dan kebijakan instansi mempengaruhi pemilihan teknik riset yang dilakukan (Wardasari, 2018). Walaupun praktisi dan peneliti public relations menganggap metodologi kuantitatif memiliki keunggulan karena orientasi disiplin praktis dengan hasil yang 'segera,' namun berdasarkan data hanya $25 \%$ mahasiswa program studi hubungan masyarakat yang menggunakan metodologi ini.

Kebijakan dan akses terhadap instansi menjadi menjadi salah satu kendala kurangnya penelitian dengan metodologi kuantitatif selain karena faktor-faktor lainnya. Pernyataan ini didukung oleh hasil wawancara dengan beberapa alumni mahasiswa program studi hubungan masyarakat tahun angkatan 2019. Penyebab rendahnya penggunaan metodologi penelitian kuantitatif dalam skripsi diantaranya, karena: a) kurangnya pemahaman mahasiswa terhadap metodologi; b) kurang referensi dari skripsi tahun sebelumnya; c) mahasiswa menganggap penelitian menggunakan instrumen angket tidak praktis; d) Sulitnya mendapat izin dan akses dari instansi yang menjadi objek penelitian; dan e) saran dari dosen pembimbing.

Berbeda dengan kuantitatif yang berusaha mengeneralisir temuan, untuk dapat memberikan hasil riset yang eksplisit dengan pengujian hipotesis yang ketat, penelitian dengan metodologi kualitatif adalah sebuah metodologi yang eklektik. Penelitian kualitatif memungkinkan peneliti untuk fokus pada detail yang lebih dalam terkait sebuah issue yang tidak dapat dinilai dengan angka-angka sederhana. Dalam kondisi yang ideal, peneliti atau public relations officer bisa menggunakan kedua jenis penelitian untuk mengkompensasi kelemahan satu pendekatan dengan kelebihan pendekatan yang lain juga untuk memperoleh data yang akurat dan menyeluruh. Sayangnya temuan peneliti di lapangan menunjukkan perbedaan signifikan antara keduanya.

Dari hasil data koding diketahui bahwa penelitian dengan kuantitatif hanya digunakan seperempat dari sampel penelitian, maka penelitian dengan metodologi kualitatif digunakan $76 \%$ dari sampel penelitian atau sebanyak 485 judul riset mahasiswa program studi hubungan masyarakat. Pada metodologi kualitatif, pendekatan yang paling banyak 
digunakan oleh peneliti adalah deskriptif.

Dilanjutkan dengan pendekatan studi kasus, fenomenologi, analisis teks, dan etnografi.

Sebuah riset terkait evaluasi metodologi dalam riset public relations dalam tiga jurnal public relations terbaik di Amerika dari tahun 1989-2007 menunjukkan penelitian kuantitatif sebanyak 186 artikel dan penelitian kualitatif sebanyak 89 artikel (Pasadeos, Lamme, Gower, \& Tian, 2011). Penelitian lain yang mengambil sampel artikel-artikel dari 12 jurnal public relations kredibel menunjukkan bahwa metodologi kuantitatif lebih banyak digunakan, dengan jumlah kuantitatif 147 artikel dan kualitatif 49 artikel (Volk, 2016). Diskusi lain menyebutkan bahwa penggunaan metode kuantitatif dalam riset public relations dikarenakan para peneliti public relations ingin membuktikan bahwa disiplin ilmu public relations adalah bidang keilmuan yang serius. Sepertinya hal ini belum dipahami oleh lulusan public relations. Mahasiswa melakukan penelitian hanya sebagai prasyarat kelulusan jenjang sarjana, sehingga penelitiannya tidak banyak terikat pada aturan dan kebijakan perusahaan. Pergeseran metodologis seperti itu akan membantu untuk menjawab pertanyaan "mengapa" dan "apa" dan menunjukkan validitas dan reliabilitas yang lebih tinggi dari temuan penelitian (Ruler, Vercic, \& Vercic, 2009).
Penelitian kualitatif, mempunyai prinsipprinsip utama yang sesuai dengan kaidah penulisan kualitatif. Diantaranya adalah baik peneliti maupun penelitiannya terikat satu sama lain, artinya peneliti membangun hubungan dengan subjek penelitian. Data riset diperoleh dari hasil wawancara, karena itu penting membangun hubungan dengan narasumber dan menghindari stereotyping.

Selanjutnya, metode fenomenologi bertujuan untuk mengetahui perjalanan hidup partisipan secara mendalam. Pada penelitian dengan metode fenomenologi, peneliti melakukan observasi kepada partisipan untuk mengetahui fenomena yang terjadi dalam kehidupan partisipan. Observasi dilakukan untuk mengumpulkan data untuk diolah kembali sehingga dapat menemukan makna dari apa yang disampaikan partisipan (Sugiyono, 2014).

Metode analisis teks dalam metode kualitatif mengkaji dan menganalisis teks secara mendalam. Objek yang digunakan merupakan teks yang telah dipublikasikan dalam majalah, surat kabar, atau media lainnya. Salah satu turunan dari analisis teks adalah Semiotika. Metode ini juga digunakan dalam beberapa skripsi mahasiswa.

Berdasarkan data yang peroleh, diketahui bahwa terdapat preferensi mahasiswa menggunakan penelitian kualitatif, dan metode deskriptif dalam skripsinya. Komposisi yang 
tidak merata ini dikhawatirkan merupakan indikator dari belum berhasilnya materi perkuliahan untuk mendorong mahasiwa meminati jenis penelitian dan metode lain. Hal ini akan berimplikasi pada kemampuan sarjana lulusan Program Studi Hubungan Masyarakat, Fikom, Unpad yang cukup terasah dalam melakukan penelitian dengan menggunakan metode tertentu saja, namun belum terampil dan teruji dalam melakukan penelitian dengan jenis dan metode yang berbeda. Padahal, jenis metode yang masih minim peminatnya di kalangan lulusan Program Studi Hubungan Masyarakat ini, tetap dibutuhkan saat mereka menjadi praktisi kehumasan di dunia kerja.

Terdapat sebuah pendapat yang menyebutkan bahwa, banyak organisasi yang tidak mengandalkan riset kehumasan dalam program kerja humas (Sulistyaningtyas, 2013). Hal ini lah yang membentuk persepsi mahasiswa humas untuk tidak terlalu fokus dalam meningkatkan kemampuan sebagai periset, yang menjadi salah satu indikator profesionalisme seorang public relations. Padahal nilai-nilai profesional selalu dianggap sebagai bagian integral dari profesi (Idid \& Fadel Arandas, 2016), termasuk profesi sebagai public relations officer.

Terlebih, medan praktik public relations juga bergeser dengan adanya media baru yang membawa peningkatan substansial (James,
2008). Sedangkan peningkatan substansi di bidang PR juga terkait dengan penguasaan beragam teori dan metode yang digunakan dalam praktik PR. Menurut pendapat yang disarikan dari sebuah penelitian terkini menyebutkan bahwa penelitian topikal utama yang telah dipengaruhi oleh teori Habermaas adalah hubungan masyarakat (Buhmann, Ihlen, \& Aaen-Stockdale, 2019). Sedangkan, dalam hasil telaah atas skripsi mahasiswa Program Studi Hubungan Masyarakat, tak ada satupun yang menggunakan teori ini. Oleh karena itu, pemberian materi dalam setiap mata kuliah dan riset di bidang Humas sebaiknya tidak hanya berfokus pada unsur praktek, namun juga pengayaan kajian teoretis (Kriyantono, 2020).

Hal ini berimplikasi pada perlunya diusulkan formulasi baru tentang hubungan masyarakat (public relations). Hal ini diperlukan karena semakin beragamnya penelitian public relations, dengan beragam paradigma yang digunakan oleh para sarjana untuk menjelaskan karakteristik dan efek public relations (Edwards, 2012). Keragaman penelitian di bidang public relations yang dipicu dengan perkembangan teknologi yang membawa perubahan ilmu public relations, memberi peluang bagi pengelola Program Studi Hubungan Masyarakat untuk semakin menajamkan positioning dengan menentukan kekhasan dari program studi, yang membedakannya dengan Program Studi 
Hubungan Masyarakat yang ada di perguruan tinggi lain.

Penentuan kekhasan program studi dapat dimulai dengan melakukan pemetaan tingkat kepuasan user atas performa dan kinerja lulusan di dunia kerja, yang dapat ditinjau dari aspek link and match antara kompetensi yang dimiliki lulusan dengan kebutuhan user. Untuk selanjutnya, hasil dari penentuan kekhasan dapat digunakan untuk penajaman positioning program studi. Adapun hasil dari penajaman positioning ini diharapkan dapat mempermudah program studi dalam melakukan branding kepada publik akademisi, user, maupun masyarakat umum, sehingga terbentuklah citra dan reputasi yang sesuai dengan harapan lembaga.

\section{SIMPULAN}

Lulusan program studi hubungan masyarakat melakukan berbagai riset dengan kajian public relations. Hasil riset tersebut dituangkan dalam skripsi yang merupakan syarat untuk mendapatkan gelar sarjana. Dalam kurun waktu tahun 2015 -2019 terdapat enam ratus tiga puluh sembilan skripsi yang dihasilkan oleh mahasiswa dengan menggunakan penelitian kualitatif dan kuantitatif dengan berbagai metode.

Hasil penelitian menunjukkan bahwa kecenderungan jenis penelitian yang digunakan lulusan program studi hubungan masyarakat adalah penelitian kualitatif dengan metode deskriptif. Penelitian kualitatif dianggap dapat menggambarkan suatu fenomena sosial dengan lebih mendalam dan dapat menghasilkan suatu penemuan yang baru dengan penggalian yang lebih mendalam. Penelitian kualitatif lebih dapat berkembang sesuai dengan kebutuhan penelitian. Rendahnya penggunaan jenis penelitian kuantitatif dalam riset kajian public relations disebabkan oleh rendahnya pemahaman mahasiswa terhadap metodologi penelitian kuantitatif, jumlah referensi yang tidak cukup banyak dari penelitian sebelumnya, anggapan bahwa teknik pengumpulan data dengan menggunakan angket tidak praktis, sulitnya akses dari objek penelitian, dan masukan dari pembimbing.

Hal ini membutuhkan respons dari pengelola program studi untuk mengantisipasi kesenjangan komposisi penggunaan metode penelitian yang dikuasai lulusannya, sekaligus melakukan evaluasi pada mata kuliah yang memiliki keterkaitan secara langsung dengan pemilihan metode dalam pembuatan skripsi mahasiswa. Temuan ini juga diharapkan dapat menjadi pertimbangan pengelola program studi untuk mulai menentukan positioning dan langkah branding lembaga guna penguatan citra dan reputasi sebagai institusi pendidikan yang bergerak di bidang public relations. Sekaligus 
memudahkan user dalam menakar kualitas dan spesialisasi kompetensi yang dimiliki lulusan yang dihasilkan oleh Program Studi Hubungan Masyarakat, Fakultas Ilmu Komunikasi, Universitas Padjadjaran.

\section{DAFTAR PUSTAKA}

Ardianto, E. (2011). Metodologi penelitian untuk public relations. Bandung: Simbiosa Rekatama Media.

Buhmann, A., Ihlen, Ø., \& Aaen-Stockdale, C. (2019). Connecting the dots: a bibliometric review of Habermasian theory in public relations research. Journal of Communication Management, 444-467. https://doi.org/10.1108/JCOM-12-20180127

Bungin, B. (2005). Metodologi penelitian sosial. Siodarjo: Airlangga University Press.

Edwards,L.(2012). Defining the 'object'ofpublic relations research: A new starting point. Public Relations Inquiry, 1(1), 7-30. https:// doi.org/10.1177/2046147x11422149

Farouk, U. (2010). Peran public relations di perguruan tinggi negeri (ptn) dalam era badan hukum pendidikan tinggi. Dialogue: Jurnal Ilmu Administrasi Dan Kebijakan Publik, 6(1), 68-77-77. Retrieved from https://ejournal.undip.ac.id/index.php/ dialogue/article/view/425

Gani, P. K. (2013). Riset bagi praktisi humas.

Grunig, J. E. (2018). Conceptualizing quantitative research in public relations quantitative research in public relations ( $\mathrm{p}$. 88). United States: ResearchGate.

Humas, P. (2017). Prodi humas.

Idid, S. A., \& Fadel Arandas, M. (2016).
Professional values, ethics, and professionalism of public relations practitioners. Jurnal Komunikasi Malaysian, 32(1), 287-311. Retrieved from https://ejournal.ukm.my/mjc/article/ view/14781

Indarto, W. (2012). Analisis karya tulis (skripsi) tugas akhir mahasiswa program studi administrasi pendidikan periode 2008/2009 dan 2009/2010. Educhild, 01(1), 59-66. https://doi.org/http://dx.doi.org/10.33578/ jpsbe.v1i1.1625

Isbandini, I. (2016). Evaluasi literatur dengan menggunakan analisis sitiran terhadap skripsi jurusan manajemen hutan tahun 2008 di perpustakaan fakultas kehutanan UGM. Berkala Ilmu Perpustakaan Dan Informasi, 10(2), 14. https://doi. org/10.22146/bip.8831

James, M. (2008). A review of the impact of new media on public relations: challenges for terrain, practice and education. Asia Pacific Public Relations Journal, 8, 137-148. Retrieved from https://www.researchgate. net/publication/242232513_A_review_ of_the_impact_of_new_media_on_ public_relations_Challenges_for_terrain practice_and_education

Kriyantono, R. (2020). Analisis isi skripsi kehumasan di perguruan tinggi. Jurnal Aristo (Social, Politic, Humaniora) Vol., 08(1), 111-128. https://doi.org/10.24269/ ars.v8i1.2265

Kurnia, I. H., Santoso, D., \& Rahmanto, A. (2013). Strategi humas dalam meningkatkan reputasi sekolah ( studi kasus di sma negeri 1 Surakarta ). Jupe UNS, I(2). Retrieved from https://jurnal.fkip.uns.ac.id/index. php/ekonomi/article/view/2380

Mulyana, D., \& Solatun. (2007). Metode penelitian komunikasi. Bandung: Remaja 
Rosdakarya.

Na'imah, H. (2013). Pemetaan skripsi mahasiswa tahun angkatan 2005 program studi bimbingan dan konseling fakultas ilmu pendidikan universitas Surabaya. Jurnal BK UNESA, 3(1), 115-126. Retrieved from https://jurnalmahasiswa.unesa.ac.id/index. php/jurnal-bk-unesa/article/view/3265

Neaimi et al. (2016). Research in public relations. Higher Education of Social Science, 10(1), 1-10. https://doi.org/10.3968/8190

Pasadeos, Y., Lamme, M. O., Gower, K., \& Tian, S. (2011). Short communication A methodological evaluation of public relations research. Public Relations Review, 37(2), 163-165. https://doi.org/10.1016/j. pubrev.2011.01.007

Prastantri, A. S., Novianti, E., \& Romli, R. (2017). Identitas sekolah cinta budaya bangsa Indonesia pada sekolah cakra buana. Jurnal Profesi Humas, 2/1(1), 73-85. https://doi.org/10.24198/prh.v2i1.11977

Prayudi. (2013). Manajemen Isu dan Tantangan Masa Depan: Pendekatan Public Relations. Jurnal IIlmu Komunikasi, 4(1), 25-39. https://doi.org/10.24002/jik.v4i1.229

Pujianto, \& Suyoso. (2011). Analisis kecenderungan dan tren penelitian pada mahasiswa pendidikan fisika sebagai revitalisasi bidang keahlian penunjang akreditasi : studi kasus prodi pendidikan fisika fmipa uny. Prosiding Seminar Nasional Sains 2011 "Menggunakan Sains Sebagai Sarana Untuk Pembelajaran Kepribadian."

Putri, N. E., Hakim, N., \& Yamin, M. (2016). Ecologicall footprint and biocapacity analysis for flooding prevention in South Sumatera. Jurnal Mimbar, 32(1), 58-64. Retrieved from https://ejournal.unisba. ac.id/index.php/mimbar/article/view/1729/ pdf

Rini, K. S., Rusmiwari, S., \& Widodo, H. P. (2017). Peran humas dalam meningkatkan citra Universitas Tribhuwana Tunggadewi. JISIP: Ilmu Sosial Dan Ilmu Politik, 6(1), 34-37. https://doi.org/10.33366/jisip. v6i1.369

Ruler, B. Van, Vercic, A. T., \& Vercic, D. (2009). Public relations metrics research and evaluation. UK: Routledge.

Sudjana, N., \& Ibrahim. (2007). Penelitian dan penilaian pendidikan. Bandung: Sinar Baru Algensindo.

Sugiyono. (2014). Metode penelitian kuantitatif, kualitatif, dan kombinasi (mixed method). Bandung: Alfabeta.

Sulistyaningtyas, I. D. (2013). Riset sebagai ujung tombak keberhasilan program public relations. Jurnal Ilmu Komunikasi, 7(2), 171-186. https://doi.org/10.24002/jik. v7i2.190

Volk, S. C. (2016). A systematic review of 40 years of public relations evaluation and measurement research: Looking into the past, the present, and future. Public Relations Review. https://doi.org/10.1016/j. pubrev.2016.07.003

Wardasari, N. (2018). Penggunaan riset oleh praktisi public relations dalam menentukan program. Jurnal Nomosleca, 4(2018), 794 804. https://doi.org/10.26905/nomosleca. v4i2.2375

Yanto, A., \& Erwina, W. (2017). Tren perkembangan penelitian tentang literasi informasi pada penelitian mahasiswa ilmu perpustakaan dan informasi universitas padjadjaran. Jurnal Ilmu Perpustakaan Dan Informasi, 2(1), 11-20. https://doi. org/10.30829/jipi.v2i1.596 